\title{
INVESTIGATION OF FUNCTIONAL-TECHNOLOGICAL PROPERTIES OF SOYA PROTEIN
}

\author{
Oksana Kochubei-Lytvynenko \\ Educational and Scientific Institute of Food Technologies \\ National University of Food Technologies \\ 68 Volodymyrska str., Kyiv, Ukraine, 01601 \\ okolit@email.ua \\ Olha Yatsenko \\ Problem research laboratory \\ National University of Food Technologies \\ 68 Volodymyrska str., Kyiv, Ukraine, 01601 \\ olga.yatsenko88@gmail.com \\ Natalya Yushchenko \\ Department of Milk and Dairy Product Technology \\ National University of Food Technologies \\ 68 Volodymyrska str., Kyiv, Ukraine, 01601 \\ YuNM_NUFT@ukr.net \\ Ulyana Kuzmyk \\ Department of Milk and Dairy Product Technology \\ National University of Food Technologies \\ 68 Volodymyrska str., Kyiv, Ukraine, 01601 \\ ukuzmik@gmail.com
}

\begin{abstract}
There was offered and grounded the use of functional technological properties of the soya protein isolate in the technology of oil pasts. It will allows to increase the balance of the oil past composition additionally and will favor the decrease of extracting moisture during the storage term.

There was studied the dynamics of a gradient of the limit stress of soya protein: hydrated soya protein, hydrated soya protein with the temperature processing, hydrated soya protein with the preliminary keeping during $24 \mathrm{~h}$, hydrated soya protein with the preliminary keeping during $24 \mathrm{~h}$ and temperature processing during $5 \mathrm{~min}$, hydrated soya protein with the preliminary keeping during $24 \mathrm{~h}$ and temperature processing during $10 \mathrm{~min}$; hydrated soya protein with the preliminary keeping during $24 \mathrm{~h}$ and temperature processing during $15 \mathrm{~min}$.

It was established, that the hydrated isolate of soya protein is a plastic system, has enough strength.

The limit stress parameter at the variable velocity of deformation of model samples determines optimal technological parameters of preparing the soya isolate: hydromodule $-1: 8$, temperature processing $-(82 \pm 2){ }^{\circ} \mathrm{C}$, process duration 10 min with preliminary keeping during 24 hours.

As a result of the studies, there were demonstrated technological parameters of preparing the soya protein isolate for obtaining the oil past by the direct mixing with the oil base.

Keywords: soya protein isolate; stress gradient; oil past structure stabilization; oil past.

\section{Introduction}

One of prospective directions in food industry is the development of the technology of low-cal food products. These products include oil pasts, which fat mass share is from 40,0 to $49,9 \%$. Obligatory components of recipes of such products are ones, retaining moisture, providing formation of the structure, homogeneity and stability of emulsion. The products of milk processing are used for this aim - dry skimmed milk, caseinates, concentrate of whey proteins, gelatin and also polysaccharides (gum, carrageenan) and vegetable proteins $[1,2]$. Due to the
\end{abstract}


use of different stabilizers, the oil pasts consistence may be from past-like to analogous to classic cream butter.

In this direction it is prospective to use the soya protein isolate. Soya proteins [3] are remarkable for the unique amino acid composition that is practically not inferior to ones of the animal origin. Soya proteins contain practically all irreplaceable amino acids, are available and rather profitable component, so the interest to soya processing products grows at world markets of food ingredients. in blood.

Soya glycerine that is the main component of soya protein favors the decrease of cholesterol

Soya is a valuable source of vitamins, especially ones of groups B, D and E, micro- and macroelements, among which it is especially important the presence of digestible ferrum, calcium, potassium and phosphorus and unique complex of other important biologically active components $[4,5]$. Today soya protein is recommended for products of dietary and special nutrition, particularly, nutrition of sportsmen.

Soya protein found its wide use in production of different food products due to the high water-binding and fat-retaining capacities that allow to obtain products with the stable quality, to decrease losses at their production and storage.

The soya protein isolate is a refined protein product comparing with a concentrate. Thus, the protein content in textured soya products reaches $70 \%$, and in isolates $-92 \%$.

The isolate has practically no admixtures - insoluble polysaccharides and other nitrogen-free compounds, and also has a rather neutral taste and smell that essentially widens possibilities of its use.

The isolate doesn't contain anti-nutritive substances (inhibitors of trypsin), naturally contained in soya, so the assimilability degree of such protein is near $95 \%$, whereas for native soya protein - near $85 \%[6,7]$. Thus, the purposeful combination of vegetable and milk raw materials allows to save raw material resources and also to obtain oil pasts with the more balanced composition, taking into account the protein deficit in the ration of modern people.

Soya proteins are characterized by high functional-technological properties, concentrates and isolates are able to absorb fat and to retain it at thermal processing [8,9].

Soya proteins also demonstrate the emulsifying capacity. They favor the formation of emulsions such as "fat in water" with their further stabilization [10-12].

Thus, the aim of the study is to investigate the isolate of soya proteins in the composition of recipes of oil pasts as a functional-technological and enriching ingredient.

\section{Materials and Methods}

Model samples of the oil past with the soya protein isolate were prepared by mixing with the further mechanical processing during 5..10 min to the even distribution of phases, obtaining a product with the homogenous consistence.

For the studies there was used cream butter with fat mass share $72,5 \%$, moisture $-25 \%$ and soya protein isolate, with mass share of dry substances $95 \%$. Skimmed milk was used as a normalizing component (fat mass share $0,05 \%$, protein $3,2 \%$, acidity $20 \pm 1^{\circ} \mathrm{T}$ ).

Based on literary data $[1,2]$ and own preliminary studies, there was determined the ratio between the soya milk isolate and hydrating medium - skimmed milk as 1:6. The less value of hydromodule was inexpedient because of the additional evaporation of moisture at further thermal processing. That is why swelling was realized at the temperature in accommodation $(18 \pm 2){ }^{\circ} \mathrm{C}$. Model samples were prepared in the ratio of the soya protein isolate : skimmed milk as 1:6, 1:8 and 1:10. As far as time is needed for restoring the protein space structure as a result of its hydration, a model sample were also prepared with preliminary keeping during 24 hours at temperature $(6 \pm 2)^{\circ} \mathrm{C}$. Hydration was realized under conditions of lower temperatures to avoid the side microflora and, as a result, the acidity of the sample increased.

Hydrated protein isolates were subjected to thermal processing at temperature $(82 \pm 2){ }^{\circ} \mathrm{C}$ with process duration 5,10 and $15 \mathrm{~min}$ that provided the microbiological safety of a normalizing component. In further the samples were cooled to $(20 \pm 2){ }^{\circ} \mathrm{C}$ for avoiding fat rendering at mixing 
with a fatty base. If the further storage of the mixture is necessary, it was cooled to temperature $(6 \pm 2){ }^{\circ} \mathrm{C}$. Before using it was heated to $(20 \pm 2){ }^{\circ} \mathrm{C}$, because mixing of the cooled mixture with the fatty base resulted in its hardening that complicated the mixing process.

Rheological properties of the model samples were determined on the rotational viscometer «Rheotest 2» (GRANAT, Russia) with the measuring system cylinder - cylinder S/N by removing curves of deformation (current) kinetics.

Measurements were realized at temperature $20{ }^{\circ} \mathrm{C}$. A measuring cylinder (rotor) $\mathrm{N}$ was chosen for a gradient layer is distributed along the whole thickness of a product, placed in a ring gap of a measuring device of the viscometer. The measuring of a bias stress $\theta(\mathrm{Pa})$ was realized by 12 values of a bias gradient rate $\gamma$ in the diapason from 0 to $100 \mathrm{~s}^{-1}$ at the direct and reverse movement. For that, indications $\alpha$ were taken at the maximal deflection angle at the device scale [10].

The bias stress $(\mathrm{Pa})$ was calculated by the formula:

$$
\theta=\mathrm{Z} \cdot \alpha
$$

where $\mathrm{Z}$ - cylinder constant, $\mathrm{Pa} ; \alpha$ - measured parameter, number of points on the device scale.

\section{Results}

At mixing the dry isolate of soya protein with skimmed milk, there formed a rather dense plastic mass that is conditioned by protein hydration. For the effective use of water-retaining properties of a protein component, it is necessary to determine the hydromodule value, at which protein particles are maximally hydrated. The effectiveness of this process may be indirectly demonstrated by changing values of a stress gradient at different values of a deformation rate.

As it can be seen on figure 1, the type of a dependence of a stress gradient on a deformation rate is similar for all samples.

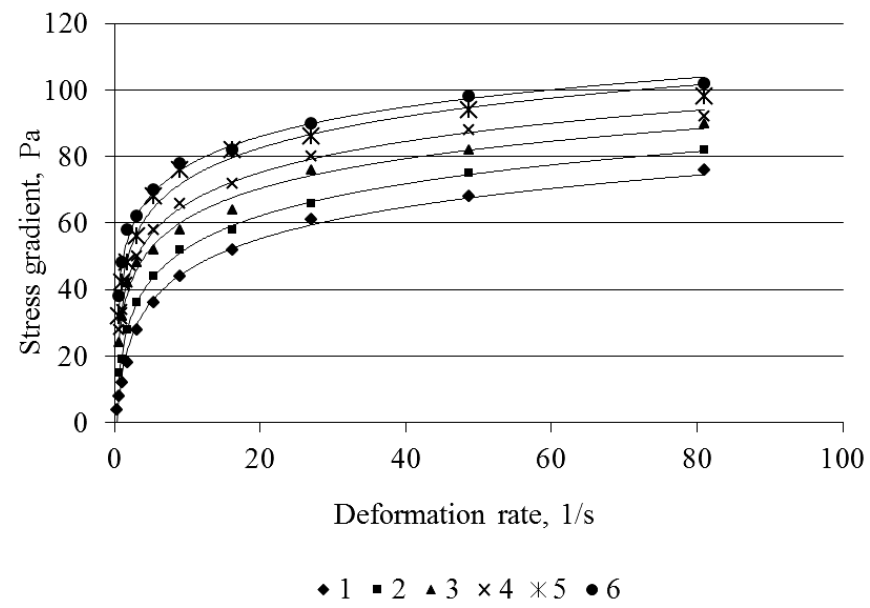

Fig. 1. Dependence of stress gradient on deformation rate for model samples as hydromodule 1:6: 1 - hydrated soya protein; 2 - hydrated soya protein with temperature processing;

3 - hydrated soya protein with preliminary keeping during 24 hours; 4 - hydrated soya protein with preliminary keeping during 24 hours and temperature processing during 5 min;

5 - hydrated soya protein with preliminary keeping during 24 hours and temperature processing during 10 min; 6 - hydrated soya protein with preliminary keeping during 24 hours and temperature processing during $15 \mathrm{~min}$

Moreover, the stress gradient value was higher for the sample, prepared with preliminary swelling during 24 hours.

The value grows for thermally processed samples, moreover, the thermal processing during 10 and 15 minutes gave the unessential increase of the gradient. Thus, it is inexpedient to conduct the thermal processing more than $10 \mathrm{~min}$. 
At the following stage, there were specified hydromodule values for the maximal use of functional-technological possibilities of the studied component. The obtained results are given in Table 1.

Based on the analysis of the data from Table 1, we can make a conclusion that hydromodule value 1:8 provides proper conditions for protein hydration. The hydromodule increase to 1:10 results in decreasing the stress gradient that testifies to the presence of free moisture, not engaged in protein hydration.

Table 1

Stress gradient of model samples at the stable deformation rate of different hydromodule values

\begin{tabular}{|c|c|c|c|c|c|c|c|c|}
\hline \multirow{5}{*}{ Sample, No. } & \multicolumn{8}{|c|}{ Stress gradient, $\mathrm{Pa}$} \\
\hline & \multicolumn{8}{|c|}{ Deformation rate, $1 / \mathrm{s}$} \\
\hline & \multicolumn{2}{|c|}{20} & \multicolumn{2}{|c|}{40} & \multicolumn{2}{|c|}{60} & \multicolumn{2}{|c|}{80} \\
\hline & \multicolumn{8}{|c|}{ Hydromodule } \\
\hline & $1: 8$ & $1: 10$ & $1: 8$ & $1: 10$ & $1: 8$ & $1: 10$ & $1: 8$ & $1: 10$ \\
\hline 1 & 60 & 50 & 68 & 68 & 76 & 72 & 82 & 80 \\
\hline 2 & 62 & 52 & 70 & 68 & 80 & 78 & 84 & 80 \\
\hline 3 & 64 & 58 & 76 & 70 & 84 & 80 & 88 & 82 \\
\hline 4 & 66 & 60 & 78 & 70 & 84 & 80 & 88 & 84 \\
\hline 5 & 72 & 62 & 86 & 72 & 88 & 82 & 96 & 86 \\
\hline 6 & 78 & 64 & 86 & 72 & 90 & 86 & 96 & 88 \\
\hline
\end{tabular}

There were studied a possibility of introducing the soya protein isolate in the fatty base, and also the maximally expedient amount of it.

The amount of the isolate, added to the fatty base, varied from 1,0 to 5,0 \% with interval $0,5 \%$. The soya protein isolate was prepared in the aforesaid way.

It was established, that the increase of the isolate amount to $2,0 \%$ didn't cause essential changes, a weak fresh taste, typical for soya, was felt. At increasing the added isolate amount to $3,0 \%$, the taste became more expressed, the consistence remained homogenous, but at chewing process there appeared the felling of heterogeneity of the sample, the feeling of softness and plasticity decreased.

It is obvious, that such amount of the soya protein isolate is not enough for obtaining oil pasts with the stable consistence and needs the additional use of water-binding components. It is expedient to create complex stabilizing systems with using components-active structure-creators.

\section{Conclusions}

There was grounded the choice of the soya protein isolate as a vegetable component for stabilizing the oil past structure.

There were determined optimal technological parameters of preparing the soya protein isolate hydromodule $-1: 8$, temperature processing $-(82 \pm 2){ }^{\circ} \mathrm{C}$, process duration 10 min with the preliminary keeping for 24 hours.

There was proved a possibility of using the soya protein isolate in recipes of oil pasts in the amount up to 2,0\% without changing organoleptic parameters of the product.

The obtained results are the base for further studies for creating effective functional complexes, based on the soya protein isolate, for the purposeful formation of the oil pasts structure, because obligatory components of such products are ones, providing the structure formation. 


\section{References}

[1] Topnikova, E. V. (2004). Study of the effectiveness of using stabilizers of the structure in the production of butter of low fat content. Storage and processing of agricultural raw materials, 5, 23-26.

[2] Topnikova, E. V. (2005). Features of the formation of the structure of butter of low fat content. Storage and processing of agricultural raw materials, 2, 34-37.

[3] Merenkova, S. P., Savostina, T. V. (2014). Practical aspects of the use of vegetable protein supplements in the technology of meat products. Applied Biochemistry and Biotechnology, 1, 23-29.

[4] Kiselev, V. M., Grigorieva, R. Z., Zorkina, N. N. (2010). Development of recipe and technology of biscuit semi-finished food with increased nutritional value. Technique and technology of food production, 4, 24-31.

[5] De Boer, R. (2017). Future proteins for application success. The word of food ingredients, 42-46.

[6] Smagina, A. V., Sytova, M. V. (2011). Analysis of the use of soy protein in the food industry. Scientific works of Dalrybvtuz, 1, 20-27.

[7] Ipsen, R. (2017). Microparticulated whey proteins for improving dairy product texture. International Dairy Journal, 67, 73-79. doi: http://doi.org/10.1016/j.idairyj.2016.08.009

[8] Pasichnyi, V. M., Strashinsky, I. M., Fursik, O. P. (2015). Investigation of emulsions on the basis of protein-containing functional food compositions. Technology audit and production reserves, 3 (3 (23)), 51-55. doi: http://doi.org/10.15587/2312-8372.2015.44177

[9] Johnson, M. E., Kapoor, R., McMahon, D. J., McCoy, D. R., Narasimmon, R. G. (2009). Reduction of Sodium and Fat Levels in Natural and Processed Cheeses: Scientific and Technological Aspects. Comprehensive Reviews in Food Science and Food Safety, 8 (3), 252-268. doi: http:// doi.org/10.1111/j.1541-4337.2009.00080.x

[10] Arltoft, D., Madsen, F., Ipsen, R. (2008). Relating the microstructure of pectin and carrageenan in dairy desserts to rheological and sensory characteristics. Food Hydrocolloids, 22 (4), 660673. doi: http://doi.org/10.1016/j.foodhyd.2007.01.025

[11] Bogdanova, N. S. (2013). Modified starches for the production of processed cheese products. Modern problems of machinery and technologies of food production. Barnaul.

[12] Pasichnyi, V., Yushchenko, N., Mykoliv, I., Kuzmyk U. (2015). Structure Stabilization of Fermented-Milk Pastes. Ukrainian Food Journal, 4, 431-439. 